\title{
Evaluation of the Contributing Factors in Development and Zoning Karst in Palangan Zone by Using Fuzzy Logic and ANP
}

\author{
Mehran Maghsoudi, Hamid Ganjaeian, Arashtalari, Khabat Amani \\ Tehran University, Tehran, Iran \\ Email:maghsoud@ut.ac.ir, h.ganjaeain@ut.ac.ir, Arash.talari@ut.ac.ir,khabat.a91@gmail.com
}

Received 28 April 2016; accepted 25 June 2016; published 28 June 2016

Copyright (C) 2016 by authors and Scientific Research Publishing Inc.

This work is licensed under the Creative Commons Attribution International License (CC BY). http://creativecommons.org/licenses/by/4.0/

c) (i) Open Access

\section{Abstract}

Karst areas are important in providing water resources, so that about 27 percent of the world population is using karst water resources. Palangan zone is located in the northwest of Iran and in Zagroos zone. According to the particular geological conditions, suitable climatic conditions, existing network of faults and fissures, this area is changed to a karst area. Due to the importance of this region in providing water, observing and studying that seems necessary. The present study is based on the field, tools and library methods. In present study, to observe the factors of expanding Karst in Palangan zone, 8 lithology factors such as: faults, slope, slope direction, elevation, river, vegetation cover and climate have been used. The method is as following: after providing the data layers, the coefficients and determination value by using ANP, in overlap GIS, unification and also providing fuzzy Logic with the help of fuzzy map are done. At the end, the studied region is divided in to four sections regarding the development. The gained results indicated: the southern and the western studied sections are having the highest expansion according to the fact that formed in pillar-less formation and also due to the existence of fault network and various seams and very humid climatic conditions, but the northern and the eastern sections are having the lowest development, due to unavailability of limestone formations, southern direction, the unavailability of seams and fractures and also semi-humid climate conditions.

\section{Keywords}

Palangan, Karst, ANP, Phase

\section{Introduction}

Karst is the result of different processes in soluble rocks under conditions of different climate, geology and

How to cite this paper: Maghsoudi, M., Ganjaeian, H., Arashtalari and Amani, K. (2016) Evaluation of the Contributing Factors in Development and Zoning Karst in Palangan Zone by Using Fuzzy Logic and ANP. Open Journal of Geology, 6, 468-483. http://dx.doi.org/10.4236/ojg.2016.66039 
hydrogeology. The Karst structures are formed more in cold and wet areas with more than 300 millimeters of rainfall with evaporated or carbonate bedrocks [1], after all, eight necessary elements to create and expand Karst are: climatic conditions, topography, geology, layers of carbonate, carbon, low temperature, pressure and tectonic setting [2], Karst processes in rocks may be started in the process of stone formation; accordingly, the role of lithological and structural features such as faults and seams as well as the factors are important [3]. In general, water content is the key factor of expanding Karst in each region, because the penetration of water inside the seams of soluble rocks could lead to develop seams and karst formations. Karst formations distribution shows that 20 percent of the continent without ice formation are formed through the carbonate and evaporate formations prone to karst and network evolution of karst groundwater is closely associated with the evolution of karst landforms [4] and also Karst water resources are considered as one of the most important sources of fresh water in the world as $27 \%$ of population in the world are using the Karst water [5]. In this regard, in the field of karstic processes, many studies have been done in Iran and all over the world.

[6] observed the role of geological formations, the karstification level, and the thickness of the aquifer and watershed area upstream feeder in the hydrogeochemical features of 6 Capra Karstic mass springs in southern Spain. [7] by observing Tarysman curve of Canines Massif springs asserted: high landing of springs indicates water discharge from large liquidation tract in the feeding bed. The relation of chemical compounds is observed with the dissolution of carbonate in three sub-basins in Turkey. In other study, [8] observed the hydrologic processes in southern Spain and concluded: In hilly areas, dry climate of the Mediterranean due to Changes in surface coating and climate, hydrologic processes in space and time is variable and due to the penetration of surface runoff along the slope, especially in sectors that have been formed from the parent material permeable limestone, the hydrologic discontinuities would be common.

In Iran the first karstic studies have been done in 1971 in Zagros, while now many studies have been conducted all over the country, such as: [9] which observed Karst expansion in Kermanshah by using GIS and AHP. They regularly observed important factors such as elevation, lithology, geomorphology, temperature, precipitation, evaporation and slope as the most important factors in creating Karst and concluded: a Bistoon calcareous mass changed more than the other formations and is likely to be richer in terms of groundwater resources. [10] observed the time of spring's death and analysis of isotopic and chemical results of Karst expansion in the sand pile by using landing coefficients. Observing the Isotope values of springs like the tritium, carbon-14 and carbon dioxide pressure level indicated that the region is Karistic. On the other hand, dieback coefficient of springs, alpha coefficient and mass volume of dynamic resources of Bistoon mass in comparison to the other springs imply the Karst expansion in the region. [11] observed Val and Vanderakh valley located in Mashhad. By observing the Karistic formations, they concluded: the existence of various seams near the faults could lead to the expansion of Karst in that area. In this regard, [12] observed Karst expansion factors in Cheleh zone in the southern province of Kermanshah. They compared the impact of different factors such as: Lithology, hydrology, land use, tectonic, elevation, rainfall and slope in the formation of karstic phenomena and concluded: among these factors, Lithological and tectonic factors are considered as the important factors in the expansion of karst. [13] by using the combination of geographic information and remote sensing techniques along with analytic hierarchy process assessed the potential development of karst in Piven anticline. The results of their research indicated: $59 \%$ of Piven anticline is in the zone with the high potential of karstification. Also [14] studied the geomorphology of karstic forms of carbonate rocks in Ahangaran region in the northeast of Birjand and concluded: in the regions with various seams, the Karistic processes could expand more. In Iran in spite of existing the Karistic mass in Zagroos, Alboorz, KopeDagh and central Iran heights, unfortunately some inconsiderable studies have been conducted in recognizing Identification of karstic unevenness, utilization management of karst water resources and tourist attractions.

In the studied region, the existence of various springs such as: Shaikh Alaedin and SarHoz indicated the close relation of underground water with karstic processes. In this regard, this issue is having close relation with many of the human activities such as: Supplying drinking water of the city and surrounding villages, agricultural water of district land, the establishment of industrial projects and tourism etc. therefore the goal of present study is observing the effect of different factors on the development of Karstic processes by using the statistical and mathematical models in Palangan zone.

The observed district: Palangan located in northwest of Kamyaran in Kordestan province in the geographical zone of 46 degree and 29 minutes of east longitude to 46 degree and 50 minutes of east longitude and longitude of 34 degree 50 minutes to 35 degrees and minutes north which are considered a part of Sahoo Karistic mountains 
(Figure 1). This district is located in the zone of high Zagros and regarding the formation is following the features of this zone. High Zagros is the longitudinal and relatively narrow strip with a width of 10 to 65 km in distance between the main fault and High Zagros [15].

\section{Materials and Methods}

The present study is based on the field, tools and library method. First by using topography maps, the scope of studied basin was defined. The main data of study are the topographic maps of 1:50,000, geological maps of 1:100,000, aerial photographs and satellite images. In present study, to observe the expansion factors of Karst in Palangan zone, 8 factors of: Lithology, fault, slope, slope direction, elevation, river, vegetation cover and climate are utilized. After providing the data layers, the coefficients and the values are calculated through ANP model.

To solve a problem by ANP method, first a network of goals, criteria, sub-criteria, options and their relations should be recognized. In the next step, paired comparison would be done. The weight of criteria and options would be gained through the super matrix of rows that have a constant value. Generally, ANP is gained through

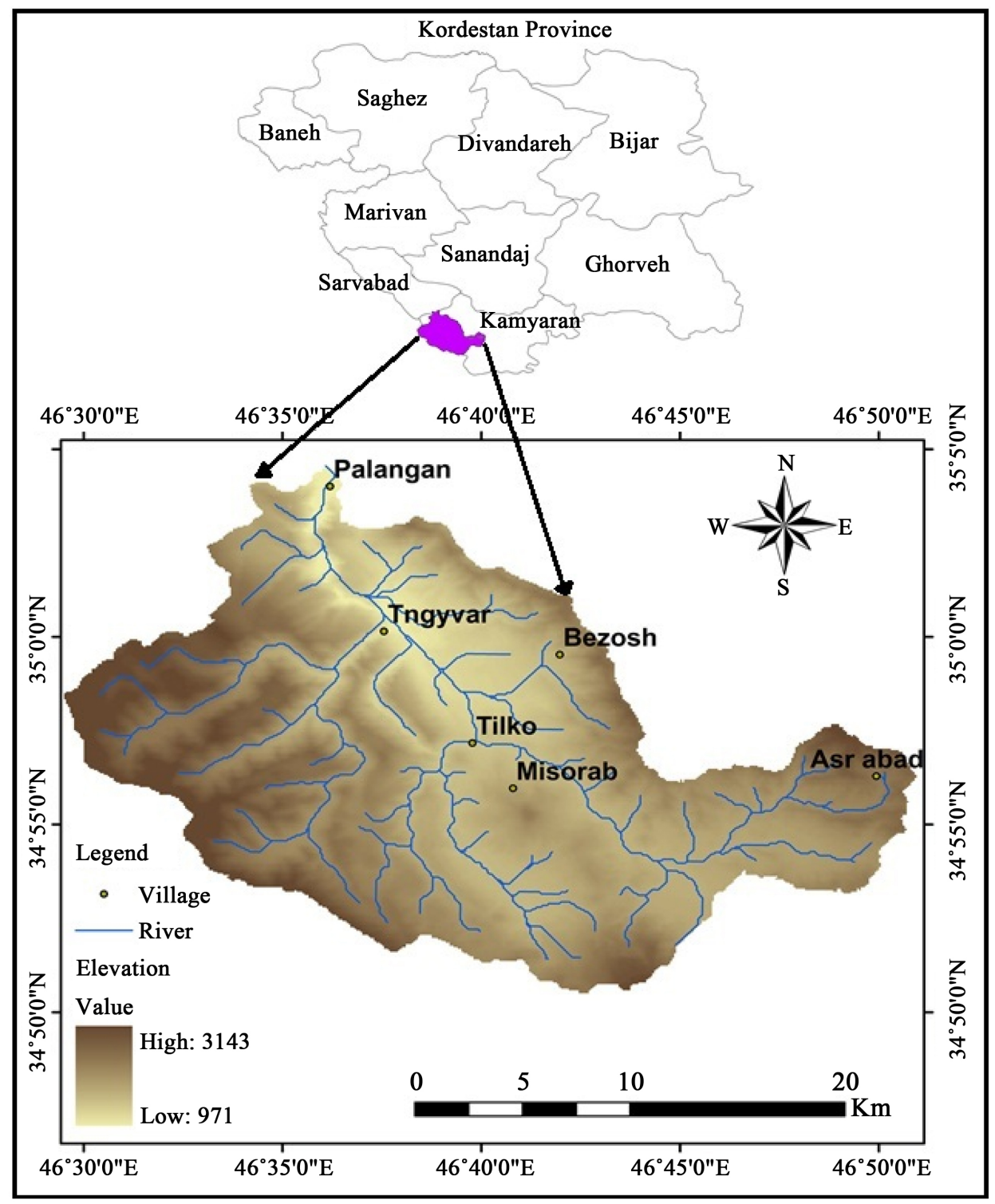

Figure 1. Location map of the study area. 
four main steps: 1-model foundation and the structure of matter 2-Paired comparison matrices and priority vectors 3-Super matrix formation 4-Choosing the best option [16], ANP could provide a condition which observes and considers the interrelationship between levels of decision-making and decision criteria in the form of a more general (Figure 2). In ANP, measuring the relative importance like AHP is done by the paired comparison and the help of 1 to 9 spectrum. Number 1 shows the importance of equality between the two factors and number 9 represents the extreme importance of a factor than other factors. In this regard, for each model 10 questionnaires have been distributed among the experts of spatial planning and 5 experts of geomorphology to score any of the ten factors. After analyzing the questionnaires, to calculate the final weights of each criteria and sub-criteria (according to the internal relation) Super Decision software is used for ANP model.

In the next stage, the influencing indices and variables in expanding Karst are sub-fuzzd using fuzzy function and in this step all the studying layers are compared in the standard form. A phase set owns a membership function with membership degree between zero and one to a series. The membership of a specified group from an objective indicates the ownership of an objective to the phase set. [17] discussed fuzzy function maps in present study are linear.

The coefficients have been transferred to the GIS polygon layer descriptive data. Transferring the coefficients to the GIS layers would lead to the decrease and also comparability of the layers. Then to perform the overlap model, the layers changed from the vector structure to the scalar by using ANP implemented coefficients and also the linear layers changed from the distance to polygon layers and then to the raster map. Finally, by overlapping considering layers, the final map was gained. For more integration of layers and removing the probable errors, the phase logic method was used. For any of the data layers which were defined in Raster frame, according to the field data, professional opinion and criteria recognition, the fuzzy function was defined (Figure 2).

According to the pattern of fuzzy function, the vegetation coverage and climate status, the first classification owns the highest value in expanding the Karstic districts and the third categorization owns the lowest value. In vegetation cover map, the first classification owns the denser vegetation coverage and as the water is having more opportunity to penetrate would have the higher score, while the third classification includes dry lands and low density districts and also the lowest potential to expand the Karstic processes. In the climate classifications also, the first classification owns very humid climate with the highest score and third classification owns the lowest score with the semi-humid climate. According to the geology pattern, limy districts in the first classification owns the highest score and basaltic districts owns the lowest potential to expand Karst in the sixth classification with the lowest score. The pattern of distance from the fault and river indicates that: the districts near the faults and also the rivers are having the higher potential for expanding the Karstic activities than the remote districts.

The slope pattern and the slope direction indicate that: the districts with the lowest slope and also the direction towards the north own the highest score. The elevation pattern also indicates that: the districts with the higher height due to delivering more humidity own more potential in expanding the Karstic processes.

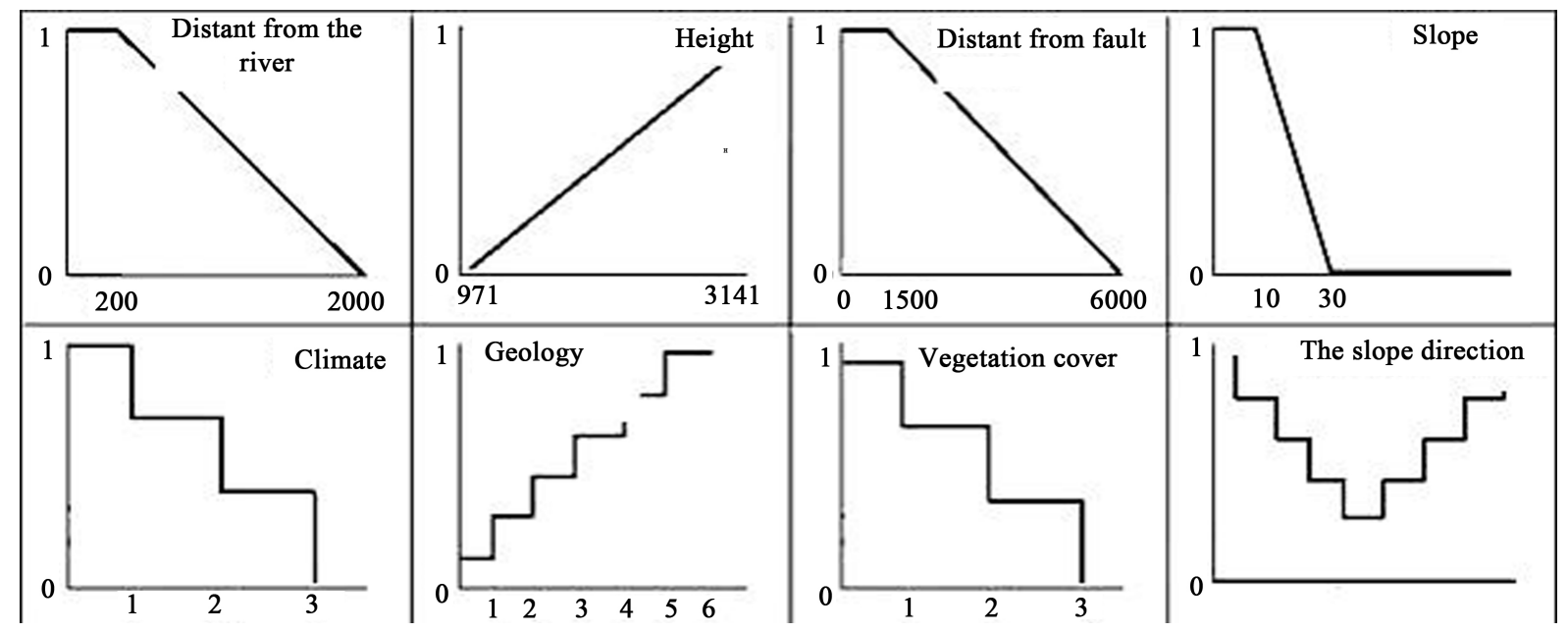

Figure 2. Fuzzy function pattern of each influencing criteria in expanding the observing karstic susceptible districts. 


\section{Discussion and Conclusion}

\subsection{Karst Expansion Factors in the Studied District}

To observe the role of effective factors in the rate of Karst expansion in the studied zone 8parameters has been used. In the following each one would be explained:

lithology: the studied district is located in high Zagroos zone and from the structural view follows the features of this zone. One of the features of high Zagroos is the existence of various thrust fault with northeast direction, but displacement isn't clear and just by thrust fault of Cambrian rocks over the Pliocene row, an image of displacement could be gained [15]. According to the geology maps of district, the rock units in the Rekhnemon district includes: Jurassic Calcareous units-Cretaceous-Paleocene-Eocene, Oligocene-Miocene and Quaternary. According to the expansion of Karstic formations in the studied zone, lithology factor is considered as the most important factor of Karst expansion. Among the formation of district, pillar-less formation with limestone lithology owns the highest expansion. The gained map from the fuzzy models and ANP indicates the priority of this formation and lithology formation (Figure 3).

Slope: in Karstic districts, the low slope districts own the highest potential to expand Karst. In the presented classification, the 0 to 10district owns the highest score and the biggest area is located in south, south east, east and north east of zone (Figure 4).

The slope direction: the best directions for the Karst expansion are the ones back to sun. The north direction is owns the highest impact in Karst and the east, west and south own the lowest impact respectively. The east and north directions in west of studied zone own the highest expansion (Figure 5).

Elevation: in different elevations, type of formation, the slope percentage, type of climate, the vegetation coverage, and river and also the percentage of penetration is different, so in different elevations, the expansion rate would be different. Accordingly, by using ANP, the studied district was classified to four classifications (Figure 6). In the third classification (2000 to 2500) the lack of dense vegetation, dense fault network and pillarless formation led to the highest rate of expansion.

Climate: according to the geographical location of the studied district located in the mountainous district of Zagroos Chain Mountains, different air masses could affect the climate. Generally, this district is affected by different masses such as (P.C), (T.M), (T.P) and (M.P) in summer (A.C), (P.C), (M.P), (MT) and (CT) in winter. According to the elevation difference of district, the climate is classified to three districts of Very humid, humid and semi humid.

In Figure 7, as high falling, especially snow in very humid district caused the highest rate of climate impact in expanding the Karst more than the other districts.

The vegetation coverage: the existence of vegetation coverage could cause more opportunity for the water penetration to the ground. Therefore, the districts with less vegetation coverage own the highest potential regarding the feeding of underground water to the other districts. As a result, there would be more possibility to expand Karstic processes. In Figure 8, the map of vegetation coverage related to the considering district is shown and the eastern regions of studied zone own more dense vegetation coverage than the other districts.

Distant from the river: the less dense the river and stream valley in Karst area is, the higher the rate of Karst expansion would be [18]. The rate of privacy and the value considered for this factor in ANP model, is the distance of 50 meters from the river and lower than the mentioned distance would gain the highest score (Figure 9).

Distance from the fault: the seams are the most important factors of water penetration to the carbonate rocks. The studied district is affected by the tectonic forces is strongly crushed. The vertical stretch of faults is Zagroos stretch i.e. northwest, southeast. There are other subsidiary faults in connection with an angle with the main fault or the same stretch. According to the gained results from the used models, the tectonic factor is considered as the most important factor of Karst expansion after lithology factor. The map of faults in the district gained though fuzzy model and ANP (Figure 10) indicates the high importance of faults in expansion of Karst in the district.

\subsection{Determining the Importance Level of Each of the Variables}

After gaining the data layers, network analysis model was used for weighting them. In this regard, after forming the comparative structure and matrix including 8 rows and columns through the questionnaire and opinions of the related experts, to determine the relation and importance of each criterion and sub-criterion are used (for instance Table 1) to perform the calculation, Super Decisions software was used and after forming the super matrixes, the weights or the values of each criterion (Table 2) and their internal relations towards the goal of study 


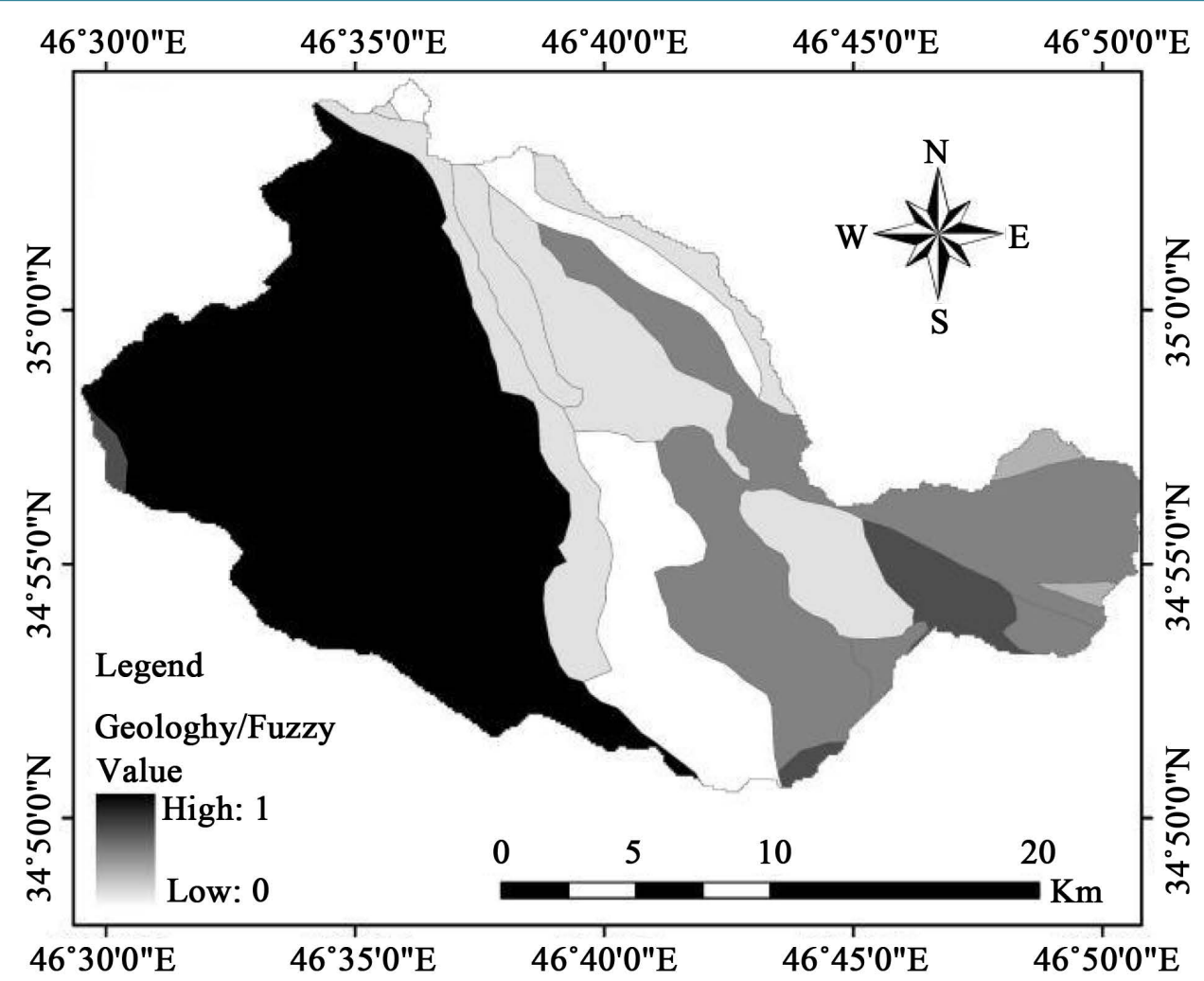

(a)

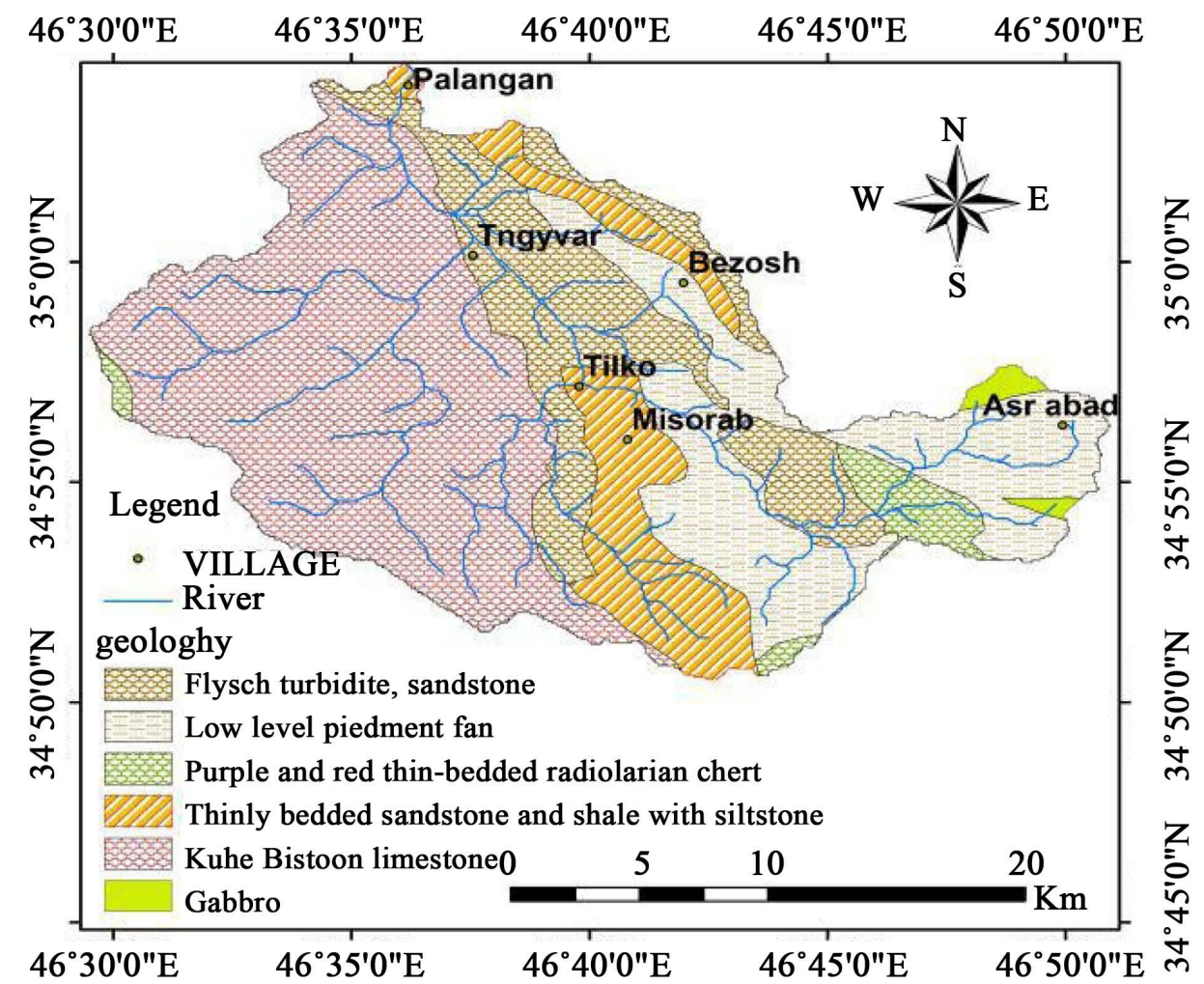

(b)

Figure 3. (a) The fuzzy map of geology; (b) The map related to the geology status of studied district. 


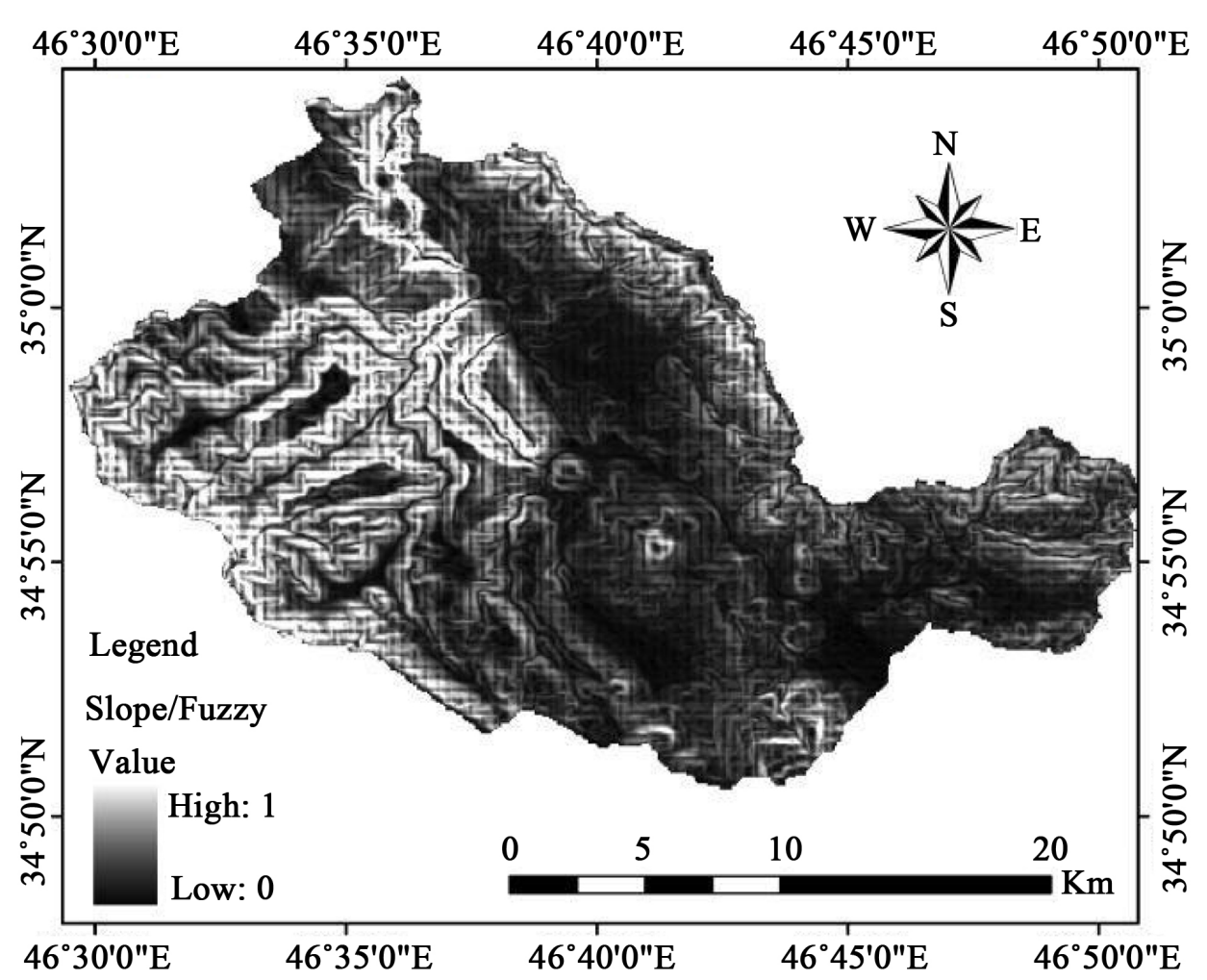

(a)

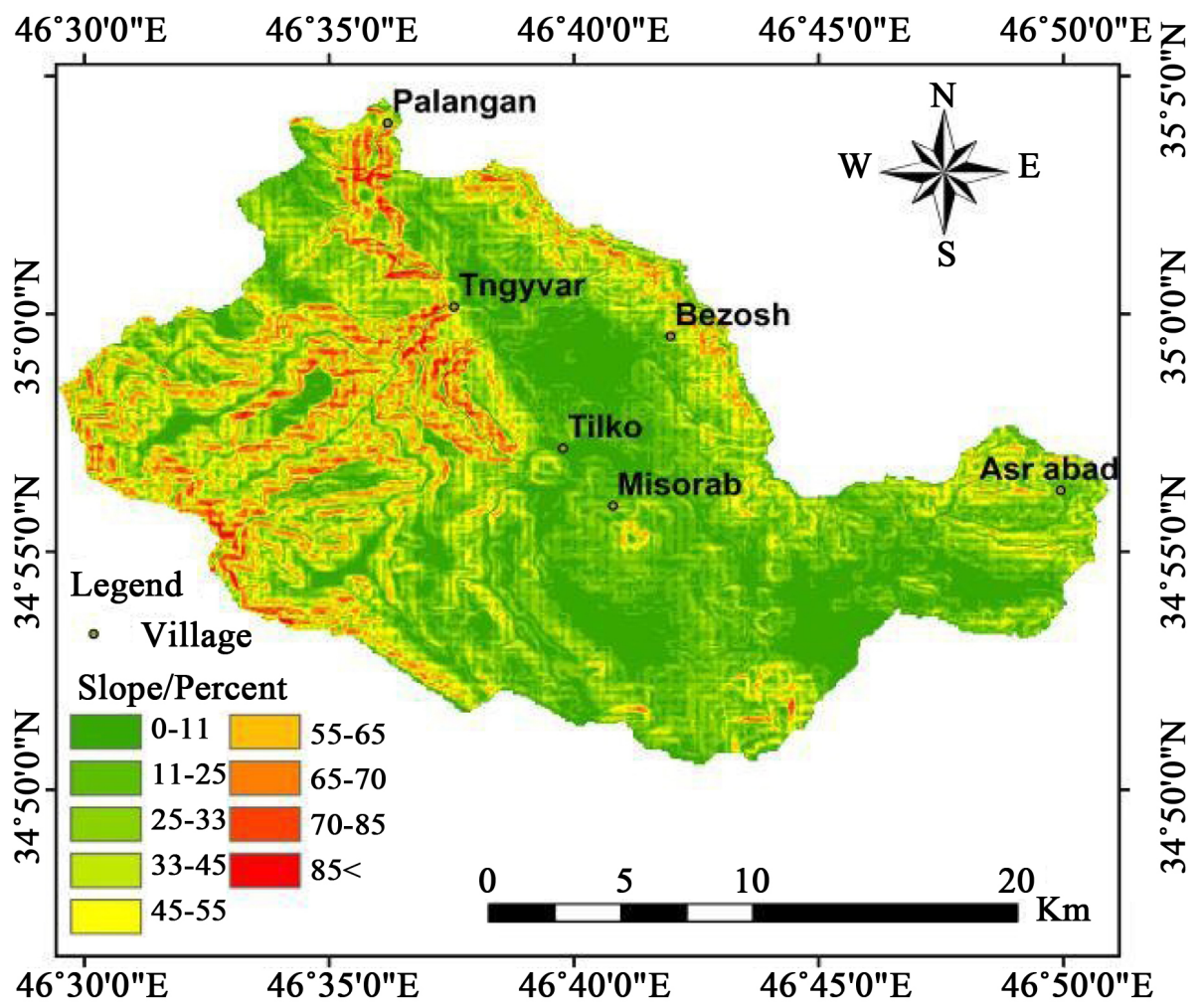

(b)

Figure 4. (a) The fuzzy map of slope; (b) The slope map of studied district. 


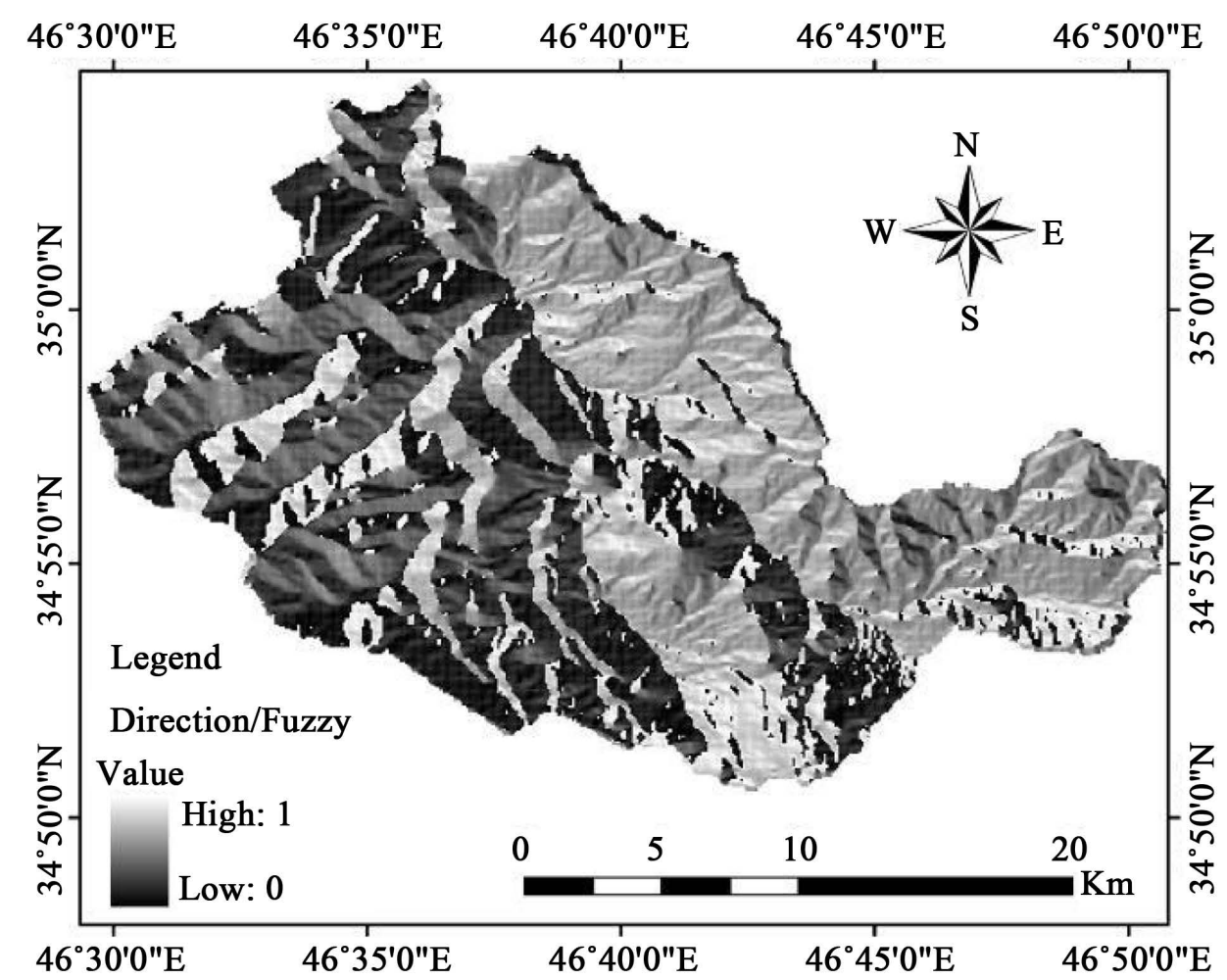

(a)

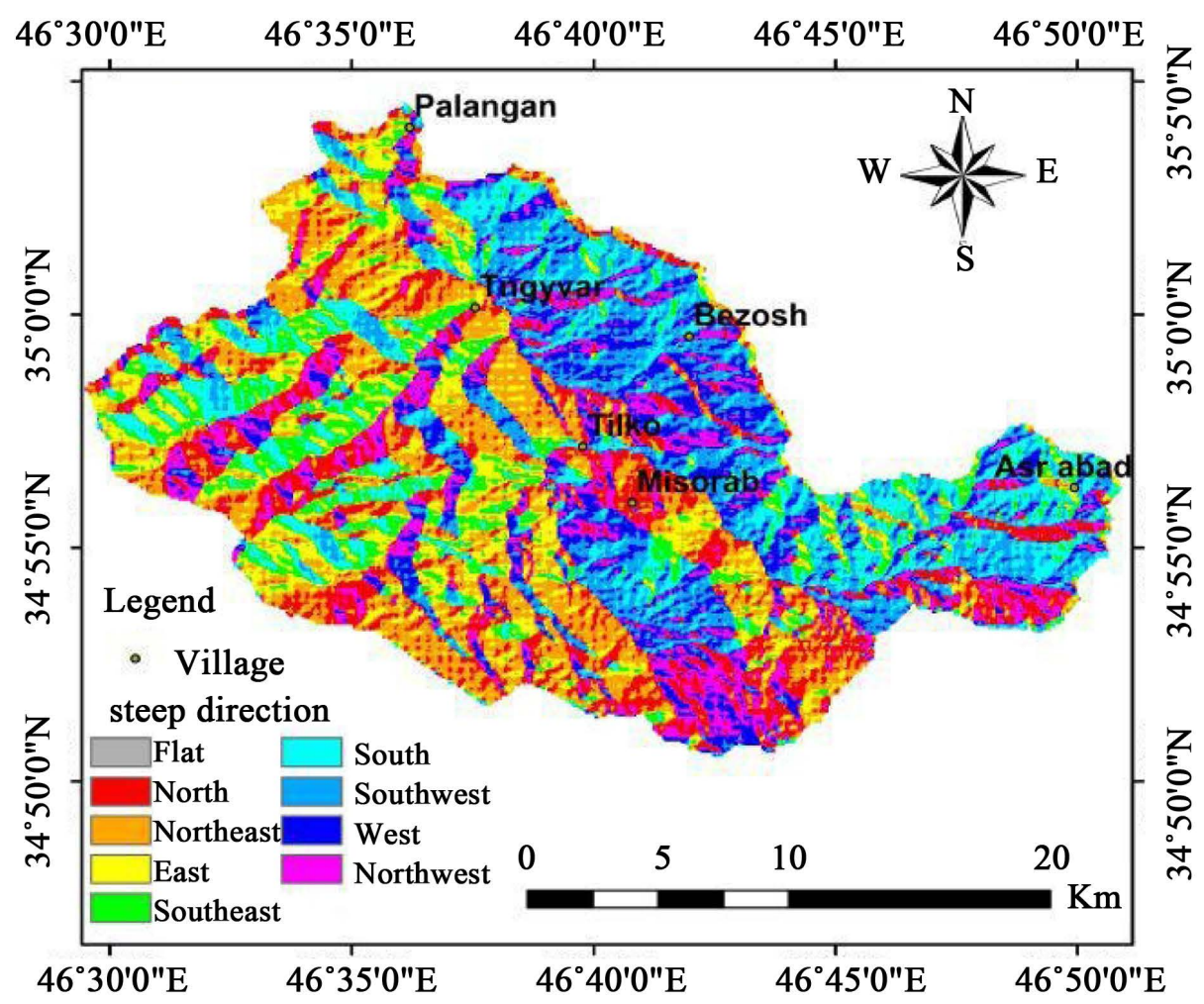

(b)

Figure 5. (a) The fuzzy map of slope direction; (b) The slope direction map of studied district. 


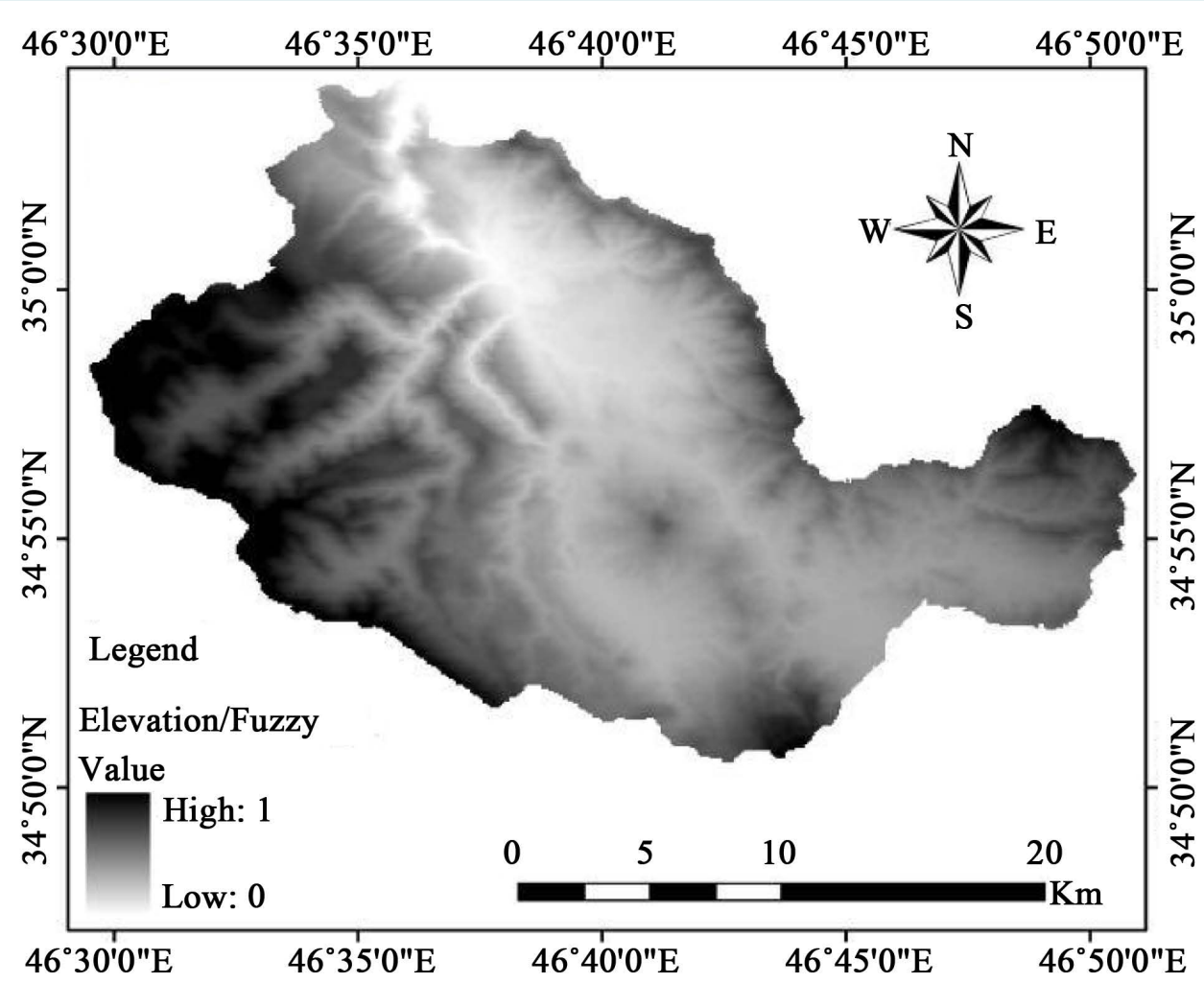

(a)

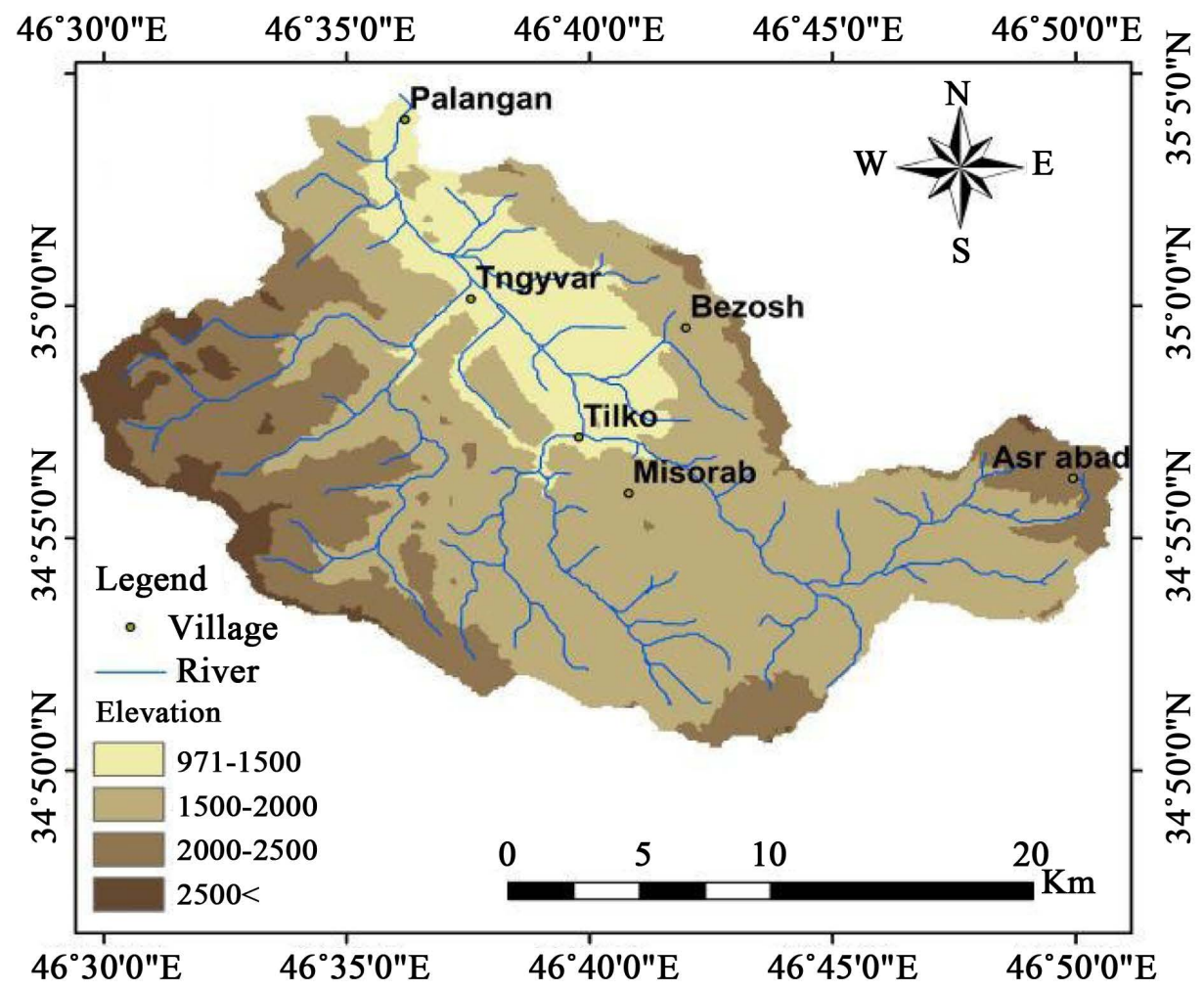

(b)

Figure 6. (a) The fuzzy map of elevation; (b) The elevation map of studied district. 


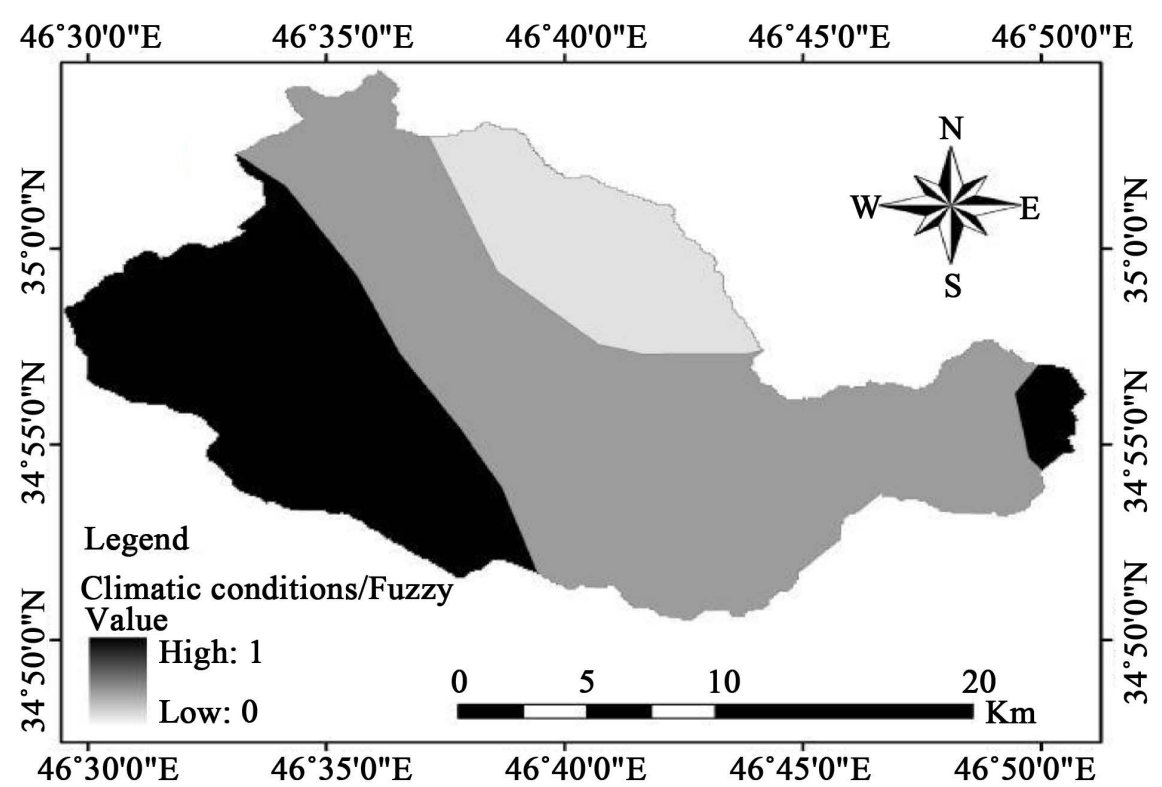

(a)

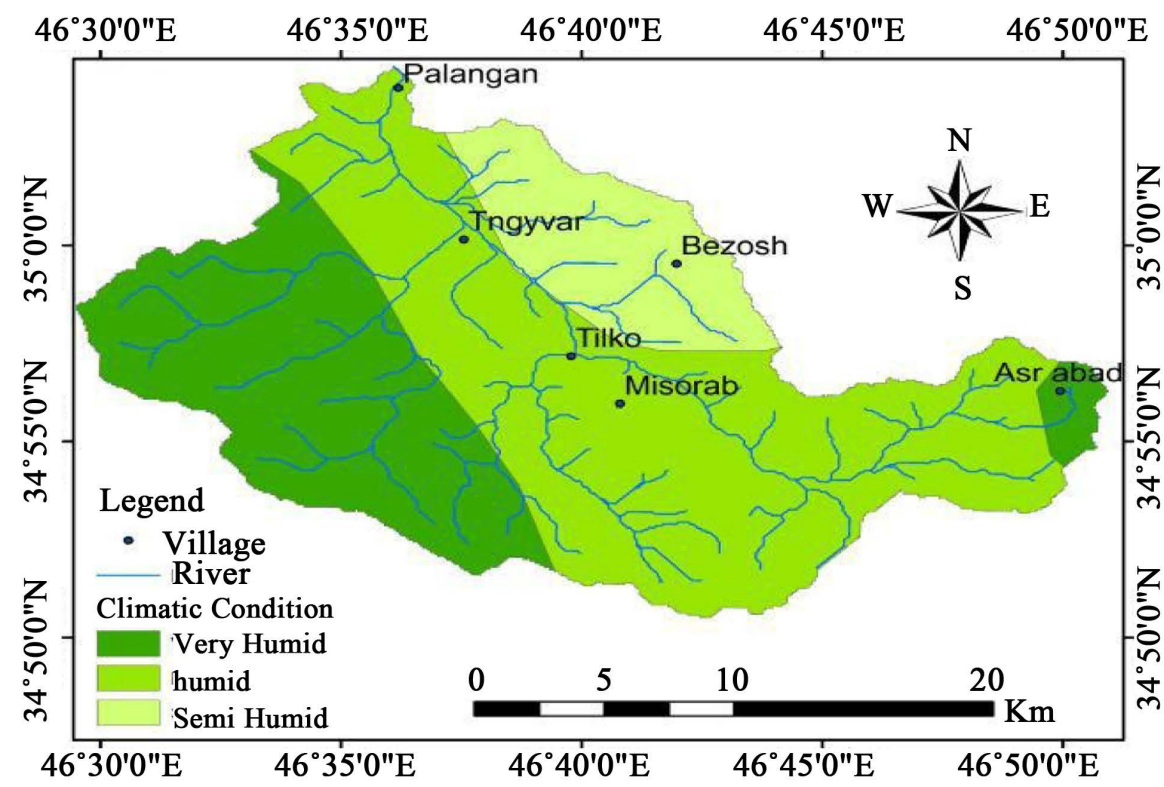

(b)

Figure 7. (a) The fuzzy map of climate; (b) The climate map of studied district.

have been gained. The final weight for each sub-criterion (according to the internal relation) was calculated in Super Decisions software and entered the descriptive table of each related layers in Arc GIS.

\subsection{Compilation of Data Layer in GIS}

In GIS all factors changed from figure to the raster on the studied zone of reference network. To gain the final weight of out-group as the criterion for the zoning, in-group and out-group normal weight coefficient (the gained eight from the sub-criterion) was used in form of network in ANP method and finally, the gained weight was multiple in ARC GIS software by using Raster Calculator in Raster layers and also by using fuzzy logic, the map was networked and integrated in the studied zone. To balance high sensitivity fuzzy operator of multiplication and 


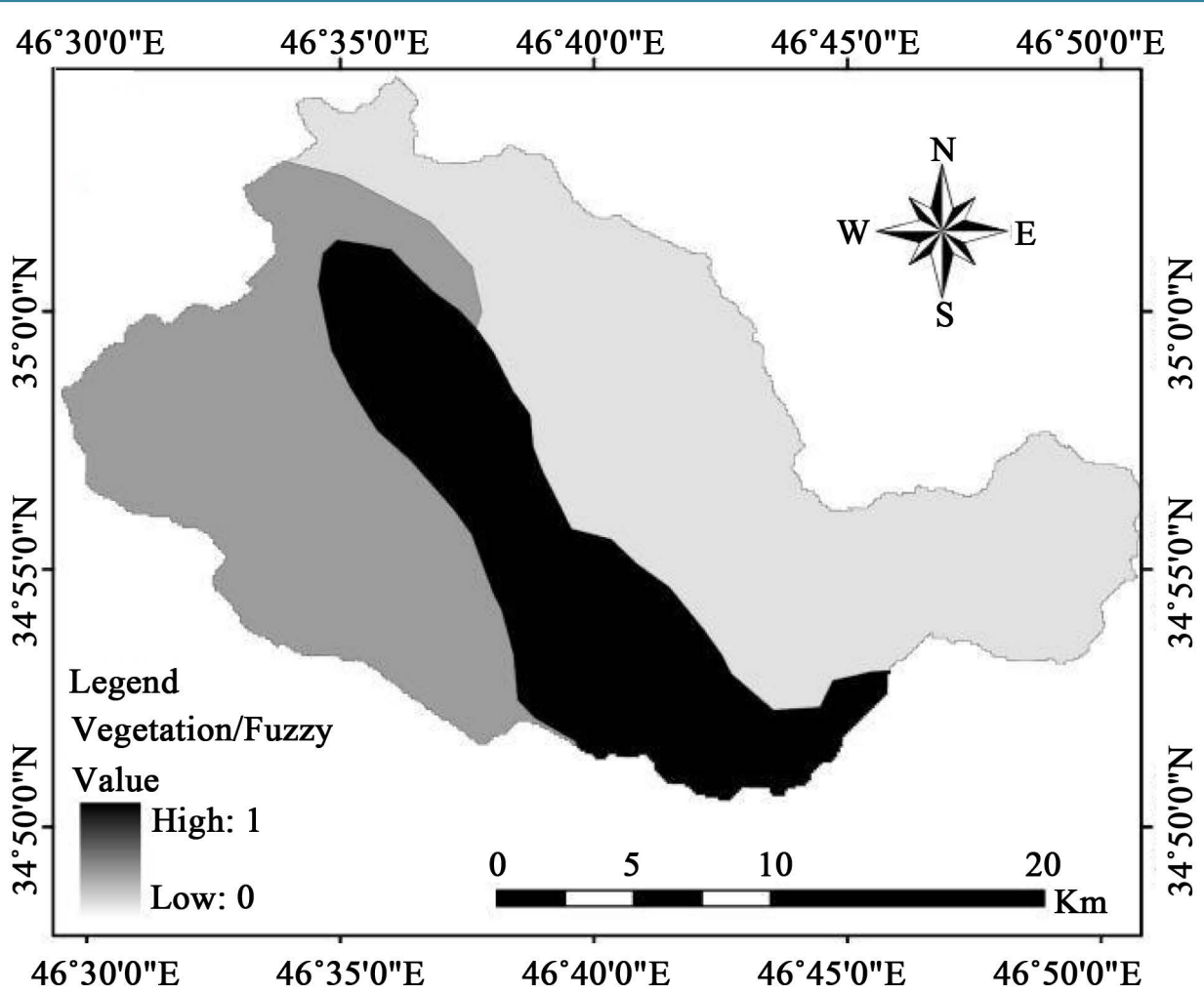

(a)

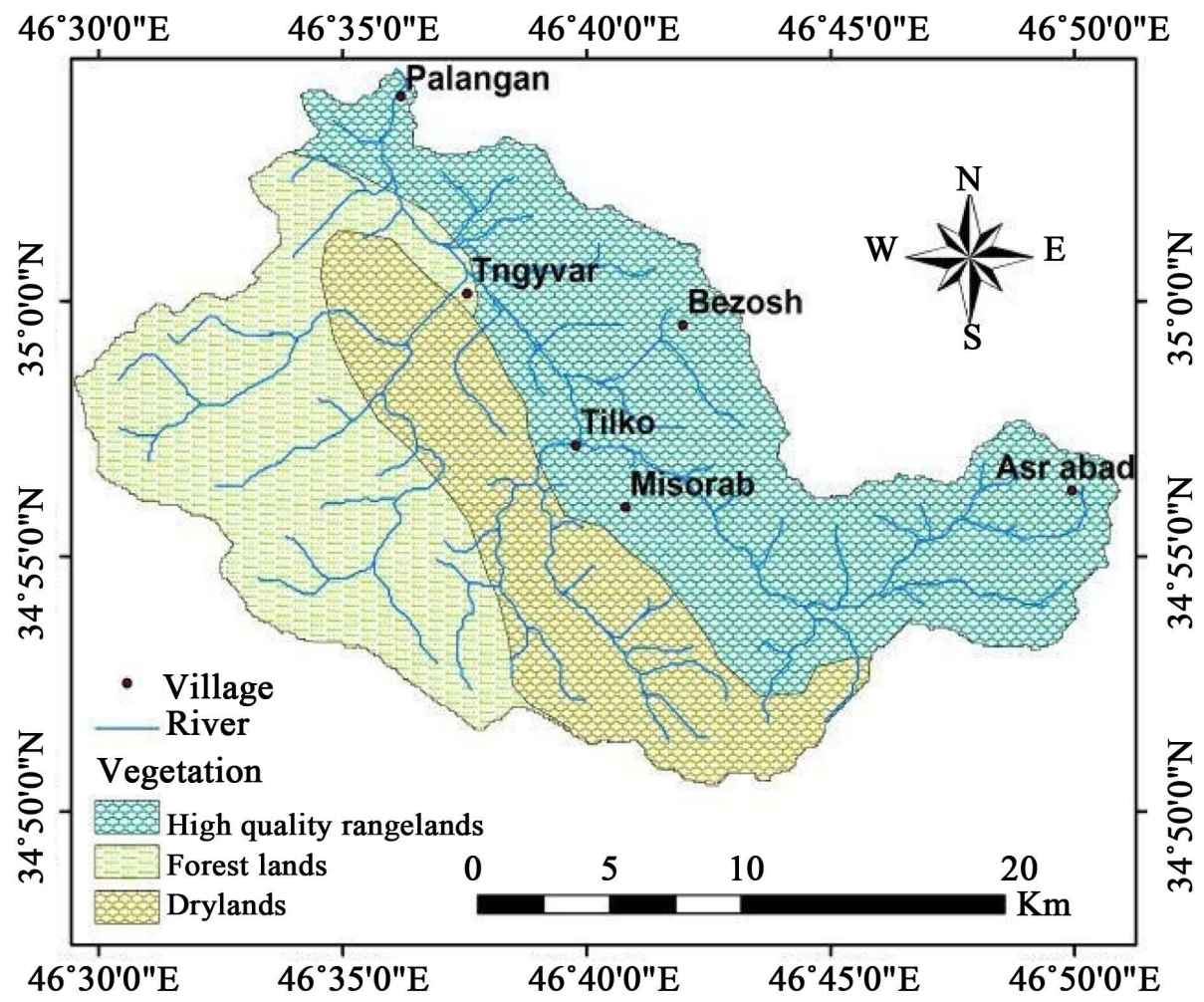

(b)

Figure 8. (a) The fuzzy map of vegetation coverage; (b) The vegetation coverage of studied district. 


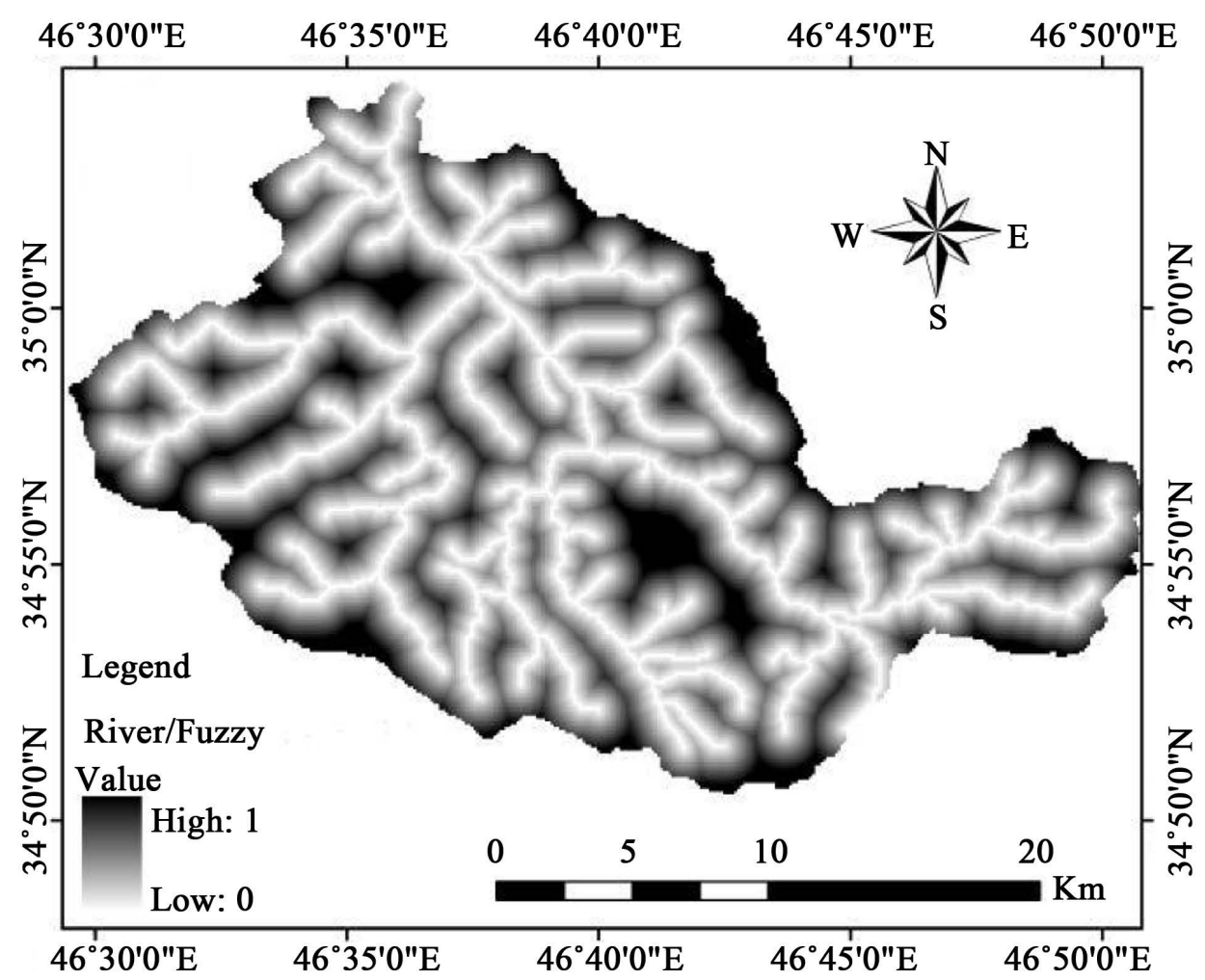

(a)

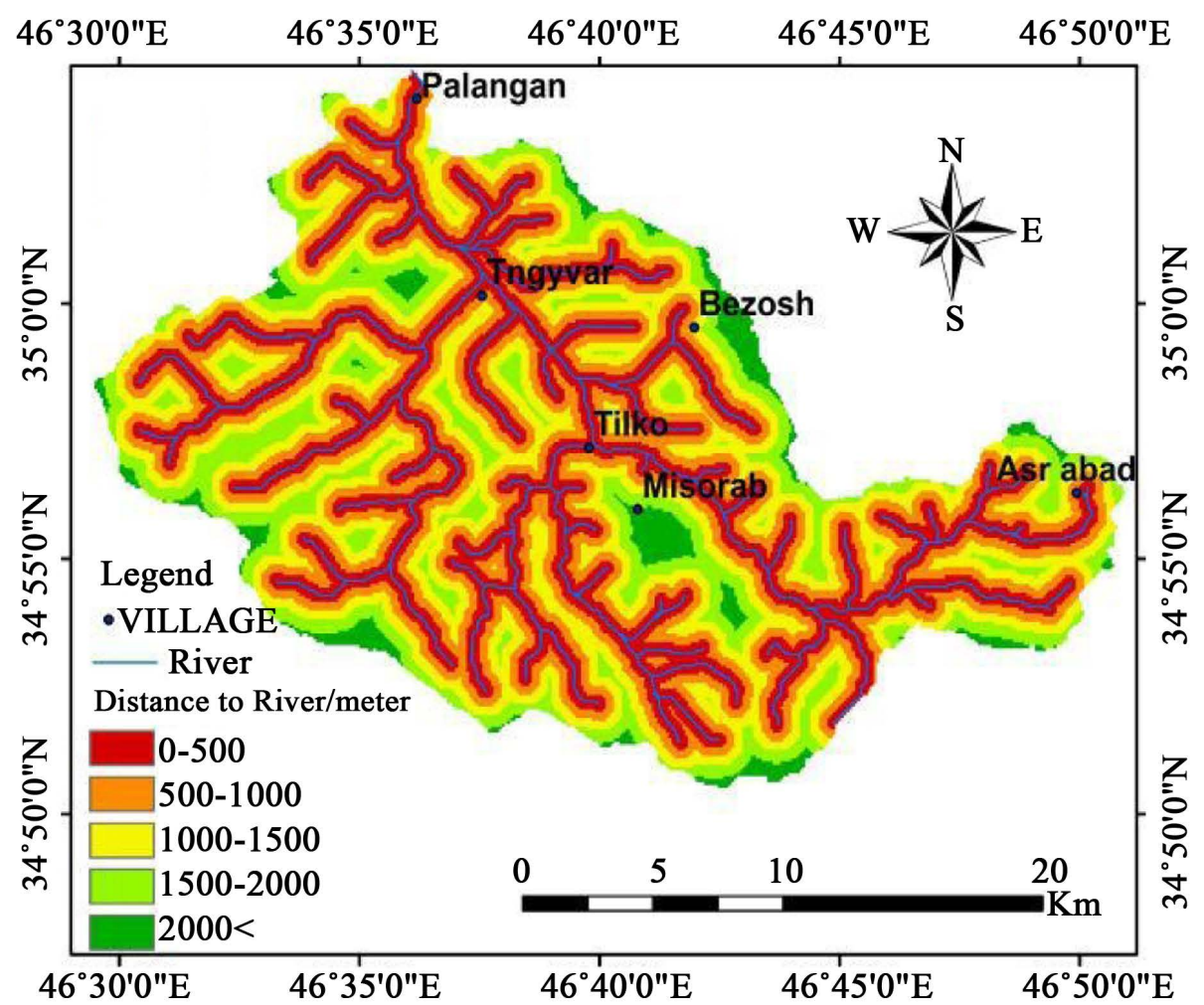

(b)

Figure 9. (a) Fuzzy map of distance from the river; (b) The distance map from the studied river. 


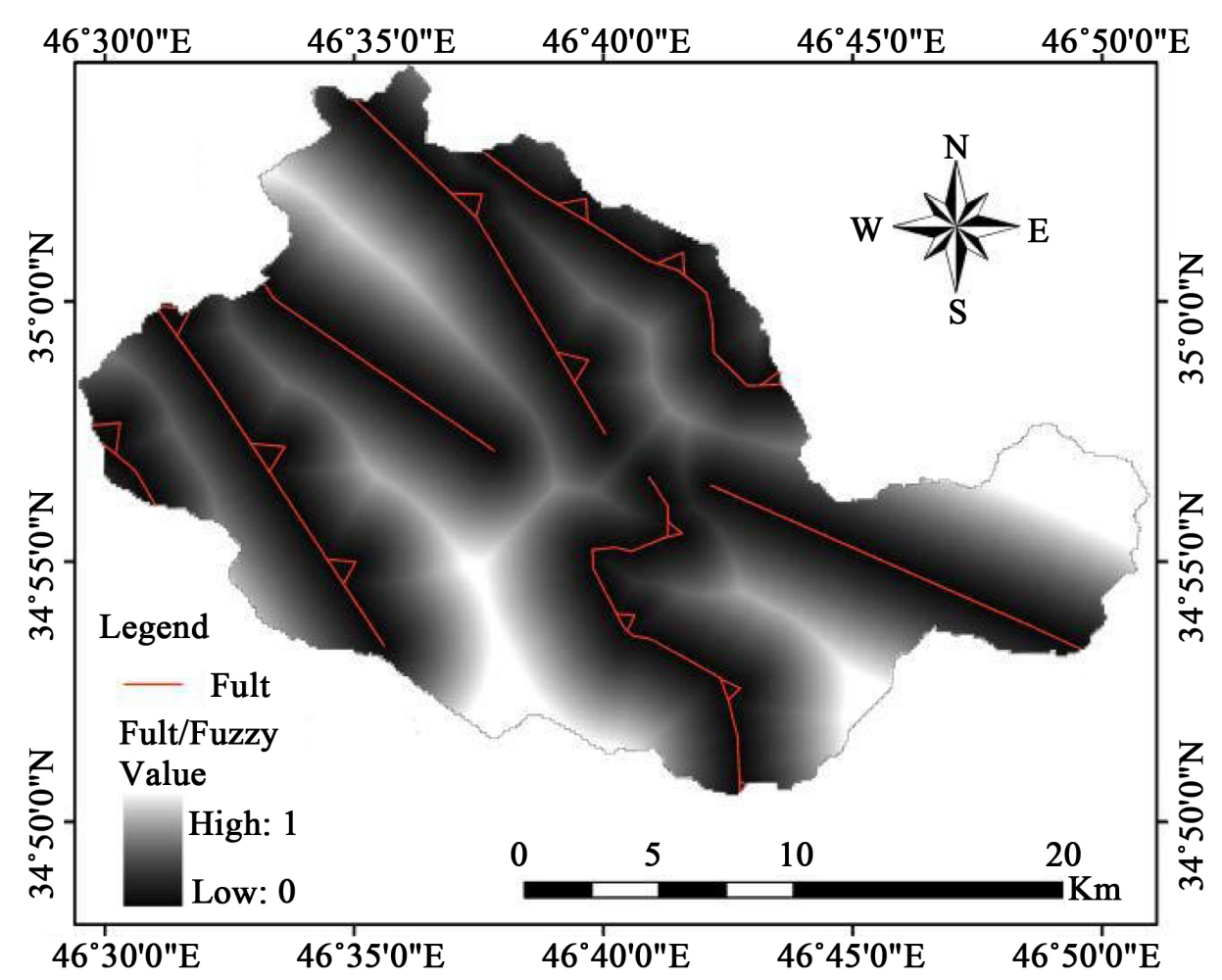

(a)

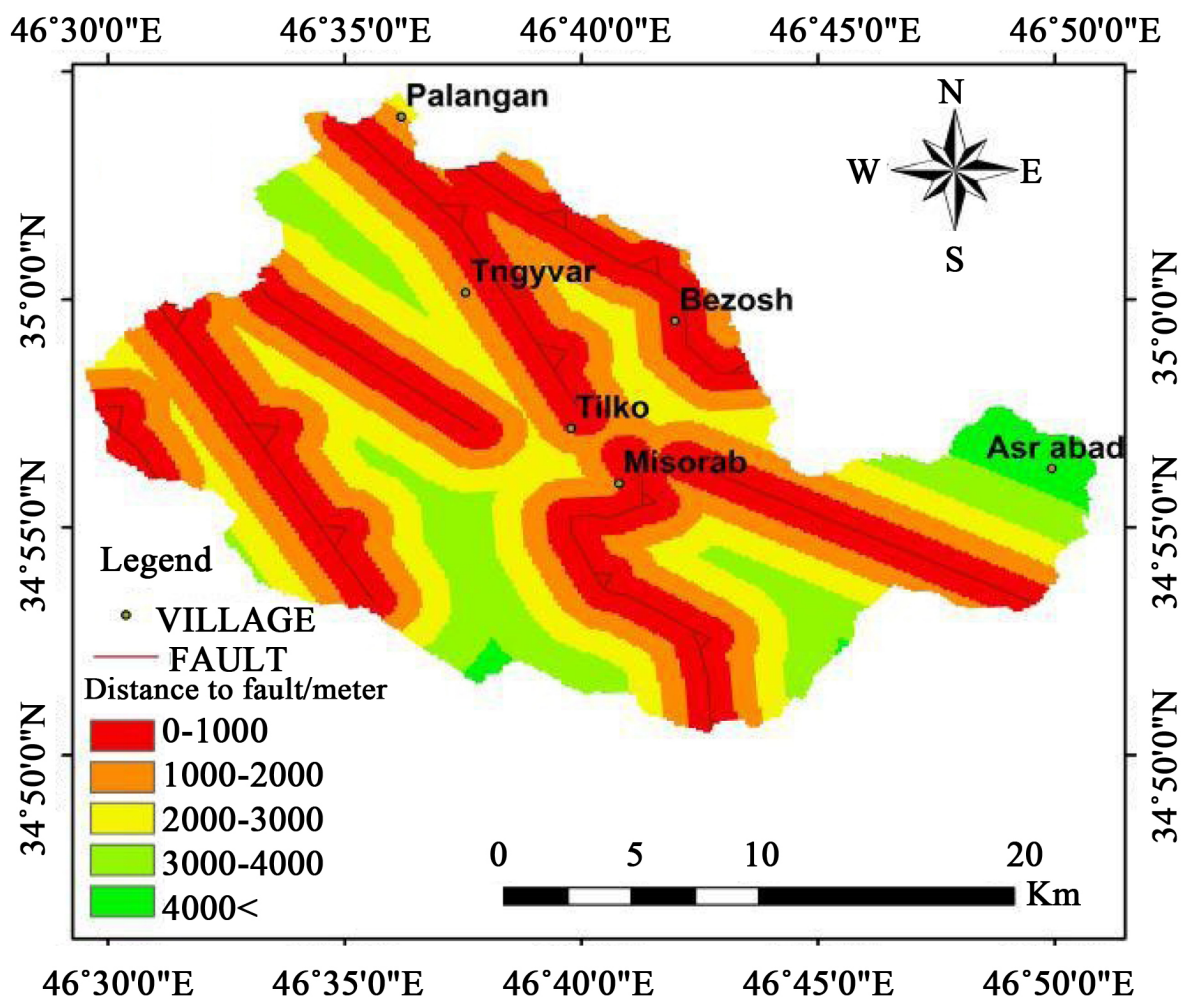

(b)

Figure 10. (a) Fuzzy map of distance from the fault; (b) The map of distance from the fault related to the studied district. 
Table 1. A sample of paired comparison (lithology criterion with the other criteria).

\begin{tabular}{|c|c|c|c|c|c|c|c|c|c|c|c|c|c|c|c|c|c|c|}
\hline \multirow{2}{*}{\begin{tabular}{|l} 
criterion \\
lithology
\end{tabular}} & \multicolumn{17}{|c|}{ The importance rate } & \multirow{2}{*}{$\begin{array}{l}\text { criterion } \\
\text { lithology }\end{array}$} \\
\hline & 9 & 8 & 7 & 6 & 5 & 4 & 3 & 2 & 1 & 2 & 3 & 4 & 5 & 6 & 7 & 8 & 9 & \\
\hline Slope degree & 9 & 8 & 7 & 6 & 5 & 4 & 3 & 2 & 1 & 2 & 3 & 4 & 5 & 6 & 7 & 8 & 9 & lithology \\
\hline Slope direction & 9 & 8 & 7 & 6 & 5 & 4 & 3 & 2 & 1 & 2 & 3 & 4 & 5 & 6 & 7 & 8 & 9 & lithology \\
\hline elevation & 9 & 8 & 7 & 6 & 5 & 4 & 3 & 2 & 1 & 2 & 3 & 4 & 5 & 6 & 7 & 8 & 9 & lithology \\
\hline climate & 9 & 8 & 7 & 6 & 5 & 4 & 3 & 2 & 1 & 2 & 3 & 4 & 5 & 6 & 7 & 8 & 9 & lithology \\
\hline $\begin{array}{l}\text { Vegetation } \\
\text { coverage }\end{array}$ & 9 & 8 & 7 & 6 & 5 & 4 & 3 & 2 & 1 & 2 & 3 & 4 & 5 & 6 & 7 & 8 & 9 & lithology \\
\hline river & 9 & 8 & 7 & 6 & 5 & 4 & 3 & 2 & 1 & 2 & 3 & 4 & 5 & 6 & 7 & 8 & 9 & lithology \\
\hline faults & 9 & 8 & 7 & 6 & 5 & 4 & 3 & 2 & 1 & 2 & 3 & 4 & 5 & 6 & 7 & 8 & 9 & lithology \\
\hline
\end{tabular}

Table 2. Normal weight coefficient gained through the paired observation of environmental variables in ANP.

\begin{tabular}{cccccccccc}
\hline Rows & 1 & 2 & 3 & 4 & 5 & 6 & 7 & 8 \\
criterion & geology & $\begin{array}{c}\text { Slope } \\
\text { degree }\end{array}$ & $\begin{array}{c}\text { Slope } \\
\text { direction }\end{array}$ & elevation & climate & $\begin{array}{c}\text { Vegetation } \\
\text { coverage }\end{array}$ & river & Faults \\
Weight in model & $0 / 211$ & $0 / 15$ & $0 / 050$ & $0 / 11$ & $0 / 14$ & $0 / 084$ & $0 / 06$ & $0 / 195$ \\
\hline
\end{tabular}

also to balance low sensitivity Gama fuzzy operator have been used.

$$
\mu=(\mu \text { fuzzy sum })^{y} \times(\mu \text { fuzzy product })^{1-y}
$$

In above equation, $\mathrm{Y}$ is determined between 0 to 1 . The conscious choice of $\mathrm{Y}$ could lead to the creation of value in output indicates the flexible adjustment of multiple downward trend and sum upward trend (Alshaikh 2008). Finally, after overlap, the map of talented districts for Karst was gained based on two fuzzy models and ANP in the studied zone (Figure 11).

\section{Conclusions}

According to the gained results from the affecting factors in expanding Karst, the observed district could be classified into four districts of: expanded, average expanding, low expanding and unexpanded. In both fuzzy and ANP maps, the districts with low expansion, own the highest area in the district and the percentage of each district is shown in fuzzy and ANP maps in Table 3.

The unexpanded districts: among the influencing factors in geology status Karstic and also the climate condition of district owns the highest effectiveness. According to the fact that western and southwest studied zones are formed of pillar less formation and also the existence of very humid climate, this district owns the highest expansion.

Average expansion districts: the highest area is located in south and west and also east of studied zone discretely. These districts are formed of the pillar less formation, the humid climate, north direction with slight slope.

Low expanded districts: these districts include the highest percentage of area. The rate of expansion is less than the two others. The existence of semi-humid climate, dense vegetation coverage, the lack of fault network and geology conditions caused not considerable Karst in the mentioned district.

Unexpanded districts: the considerable part of north district and also the eastern districts of the zone are included. The existence of non-calcareous formations, high slope, semi-humid climate; high vegetation coverage, 


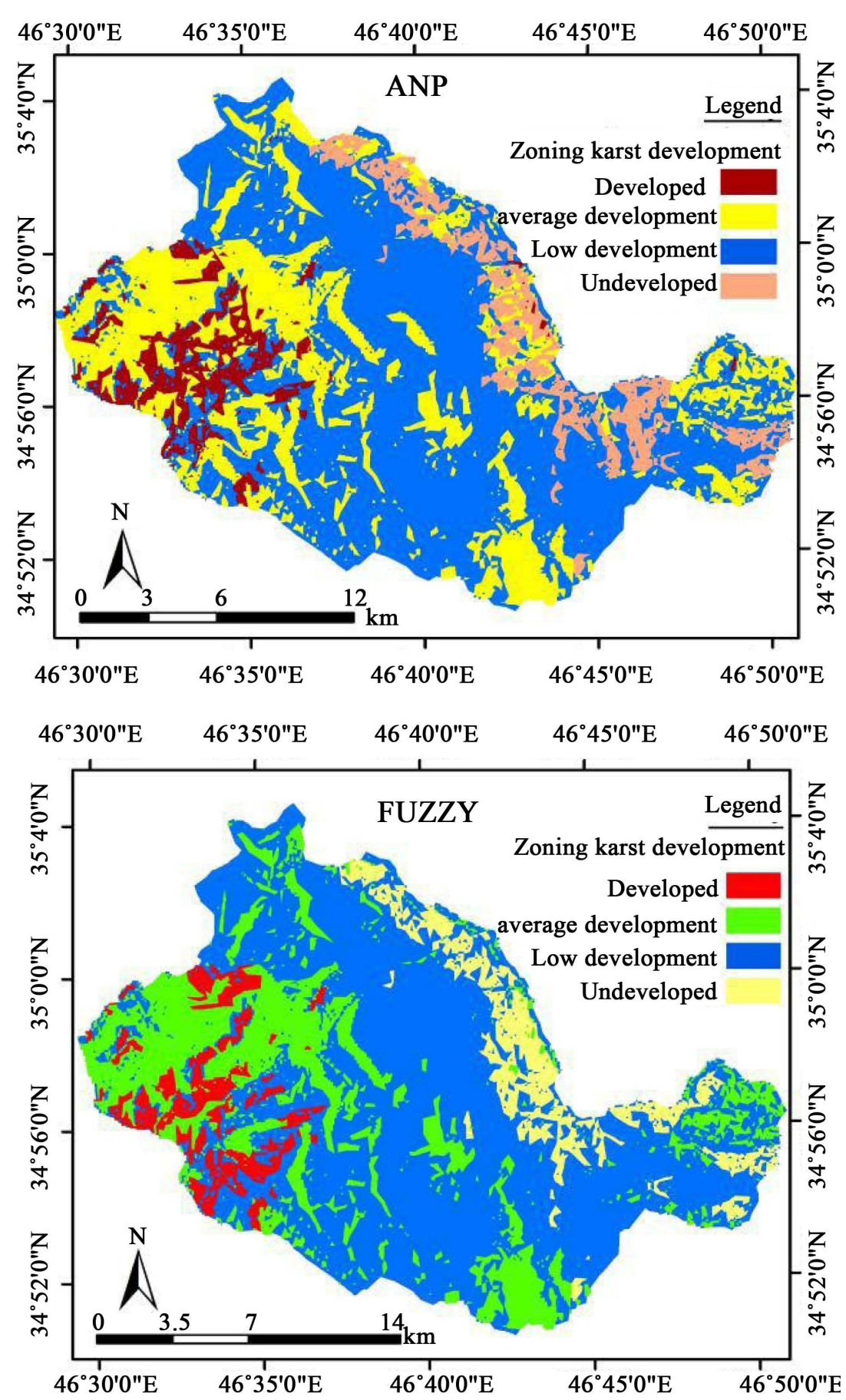

Figure 11. Karst expansion zoning of the studied district by using fuzzy model and ANP.

Table 3. Karstic classifications area percentage in the studied zone.

\begin{tabular}{ccccc}
\hline Model & expanded & Average expanding & Low expanding & unexpanded \\
\hline fuzzy & 40 & 85 & 230 & 65 \\
ANP & 45 & 95 & 225 & 55 \\
\hline
\end{tabular}

south direction slope and high elevation prevented the expansion of Karst in this district. 


\section{References}

[1] Milanovich, P. (1981) Soil Surface Conditions and Erosion Process. Translated by Afrasiabian, Standard Press, Iran.

[2] White, W.B. (1988) Geomorphology and Hydrology of Karst. Oxford University Press, Quinlan.

[3] Ford, D.C. and Williams, S (1989) Karst Geomorphology and Hydrology. 1-6.

[4] William, P. and Ford, D. (2007) Karst Hydrogeology and Geomorphology. John Wiley \& Sons Ltd., The Atrium, Southern Gate, Chichester, West Sussex PO19 8SQ, England, 1-578.

[5] Keltat, D. (1999) The Natural Geography of the Sea and Beaches. Translated by Servati, Samt Press, Tehran University, Tehran.

[6] Lopez-Chicano, M., Bouamama, M., Vallejos, A. and Pulido-Bosch, A. (2001) Factors Which Determine the Hydrogeochemical Behavior of Karstic Springs: A Case Study from Betic Cordilleras, Spain. Applied Geochemistry, 16, 1179-1192. http://dx.doi.org/10.1016/S0883-2927(01)00012-9

[7] Komac, B. (2006) The Karst Springes of the Kanin Massif Kra[Ki Izvir Pod Kanin Skim Pograje. http://www.zrc-sazu.si/giam/zbornik/komac41

[8] Ruiz Sinoga, J.D., Diaz, A.R., Bueno, E.F and Murillo, J.F.M. (2010) The Role of Soil Surface Conditions in Regulating Runoff and Erosion Processes on Metamorphic Hillslope (Southern Spain), Soil Surface Conditions, Runoff and Erosion in Southern Spain. Catena, 80, 131-139.

[9] Maleki, A., Shohani, D. and Takeghani, M. (2008) Zoning Karst Evolution in Kermanshah Province. Spatial Planning Journal, 13, No. 1.

[10] Maghsoodi, M., Karimi, H., Safri, F. and Chahrrahi, Z. (2009) Observing the Karst Expansion in Todeh Bra, Bistoon Using the Coefficient of Landing, Springs Death Time and Isotopic and Chemical Analysis, Research-Natural Geography, Number 65.

[11] Haidarzadeh, M. and Mohammadzadeh, H. (2011) Geochemical Studies and Karst Geomorphology in Sazand (A Case Study on the Andrkh Valley Located in Mashhad). Proceedings of the 30th Meeting of Earth Sciences, Iran.

[12] Yamni, M., Shamsipoor, A., Jafar, M. and Bagheri, S. (2011) The Affecting Factors in Expansion and Zoning Karst in Cheleh Zone by Using Fuzzy Logic and AHP. Earth Science Magazine, No. 88.

[13] Khedri, A., Rezaee, M. and Ashjari, J. (2011) Observing the Potential of Karst Expansion in the Anticline Piven Using Integrated GIS and Remote Sensing along with Analytic Hierarchy Process. Journal of Research in Water Resources, Issue 28.

[14] Miealaee, M., Gholamreza, M., Etebari, B. and Hayhat, M. (2013) The Introduction of Karstic Carbonate Rocks in Ahangaran District (North East of Birjand). Journal of Geography and Urban Planning—Regional, 3, No. 8.

[15] Aghanabati (2005) Geological Survey of Iran. Senubar Press, Geological Survey and Mineral Exploration Organization

[16] Momeni, M. and Sharifi, A. (2011) Multi-Criteria Decision-Making Models and Software. Moalefin Press, Iran.

[17] Al-Mohseen, K.A.A. (2009) Drought Index Assessment for Fatha Region Using Fuzzy Logic Approach. Proceedings of the Georgia Water Resources Conference, Athens, Georgia, 23-27April 2009, 1-10.

[18] Ministry of Power, Tamab (1994) Multilingual Dictionary of Karst Vocabulary. Water Resources Research Institute, Iran.

\section{Submit or recommend next manuscript to SCIRP and we will provide best service for you:}

Accepting pre-submission inquiries through Email, Facebook, Linkedin, Twitter, etc

A wide selection of journals (inclusive of 9 subjects, more than 200 journals)

Providing a 24-hour high-quality service

User-friendly online submission system

Fair and swift peer-review system

Efficient typesetting and proofreading procedure

Display of the result of downloads and visits, as well as the number of cited articles

Maximum dissemination of your research work

Submit your manuscript at: http://papersubmission.scirp.org/ 